\section{Elevated prealbumin level following high thyroid hormones levels}

\author{
Hiroyuki Kinoshita, Mutsuko Yasuda, \\ Marina Mori, Fumiatsu Yakushiji \\ Department of Internal Medicine, Tokyo \\ Metropolitan Bokutoh Hospital, Tokyo, \\ Japan
}

\section{Abstract}

This study is the first to report about a patient with high prealbumin level [ $56.8 \mathrm{mg} / \mathrm{dL}$ (reference range 22.0-40.0 mg/dL)] following elevation in thyroid hormones levels. Among the thyroid hormones, tetraiodothyronine (free T4 and total T4) level showed an elevation. Triiodothyronine (free T3 and total T3) level was within normal limits. Since prealbumin mainly transports $\mathrm{T} 4$, the elevation of prealbumin level along with T4 level is reasonable. When patients have chronic hyperthyroidism without thyroid-stimulating hormone receptor antibody (TRAb), a diagnosis will be Negative Graves' disease. However, a part of patients with Negative Graves' disease may be High prealbumin syndrome.

\section{Introduction}

In the plasma, more than $99 \%$ of thyroid hormones are bound to their carrier proteins such as thyroxine-binding globulin (TBG), prealbumin, and albumin. ${ }^{1}$ Of these, the concentrations of TBG and albumin affect the levels of thyroid hormones. ${ }^{2,3}$ However, increase in prealbumin level following increase in thyroid hormones has not been reported.

\section{Case Report}

In May 2011, a 67-year-old man was referred to the department of endocrinology of our hospital because of hyperthyroidism. In April 2011, his thyroid hormone levels were as follows: thyroid-stimulating hormone (TSH), 1.21 $\mu \mathrm{U} / \mathrm{mL}$ (reference range, 0.35-4.94 $\mu \mathrm{U} / \mathrm{mL}$ ); free triiodothyronine (FT3), $2.91 \mathrm{pg} / \mathrm{mL}$ (reference range, $1.71-3.71 \mathrm{pg} / \mathrm{mL})$; and free tetraiodothyronine (FT4), $1.77 \mathrm{ng} / \mathrm{dL}$ (reference range, 0.70-1.48 ng/dL) (Table 1).

On our hospital, the thyroid echography was performed; the results indicated slight enlargement of the thyroid with slight heterogeneity, but it did not have any space occupying lesion (SOL). The results of TSH receptor antibody (TRAb) and TSH stimulating antibody (TSAb) assays were negative but those for thyroglobulin antibody (TgAb) and thyroid peroxidase antibody (TPOAb) assays were positive (Table 1). Then, we suspected painless thyroiditis; however, thyroglobulin, a marker for thyroid destruction, was found to be within normal limits, i.e., $19.5 \mathrm{ng} / \mathrm{mL}$ (reference range, $<32.7 \mathrm{ng} / \mathrm{mL}$ ) (Table 1). Further analysis showed that prealbumin level was elevated, i.e., $56.8 \mathrm{mg} / \mathrm{dL}$ (reference range, 22.0-40.0 $\mathrm{mg} / \mathrm{dL}$ ) (Table 1). The patient has not taken any medications including corticosteroids. The patient has not been an alcoholic. The patient has not had renal diseases. The patient has not been over-nourished. We therefore could not find out the cause of elevated prealbumin.

In July 2011 and August 2011, the level of prealbumin was high-normal, i.e., $36.7 \mathrm{mg} / \mathrm{dL}$ and $37.1 \mathrm{mg} / \mathrm{dL}$, respectively. However, in November 2011, the level of prealbumin was higher than the normal limit $(48.7 \mathrm{mg} / \mathrm{dL})$. Furthermore, in January 2012, both prealbumin and total tetraiodothyronine (TT4) levels were high, i.e., $43.7 \mathrm{mg} / \mathrm{dL}$ and $11.3 \mu \mathrm{g} / \mathrm{dL}$ (reference range, 11.3 4.8-10.5 $\mu \mathrm{g} / \mathrm{dL}$ ), respectively. However, the level of thyroglobulin was found to be within normal limits $(8.4 \mathrm{ng} / \mathrm{mL})$ (Table 1); the painless thyroiditis was not suitable.

\section{Discussion}

This is the first report of a patient whose prealbumin level elevated following an increase in the thyroid hormone levels. Among the thyroid hormones, tetraiodothyronine (FT4
Correspondence: Hiroyuki Kinoshita Department of Internal Medicine, Tokyo Metropolitan Bokutoh Hospital, 4-23-15 Koutohbashi, Sumida-ku, Tokyo 130-8575, Japan.

Tel. +81.336.336151 - Fax: +81.336 .336173$

E-mail: hkinoshita-tky@umin.ac.jp

Key words: thyroid hormones, thyroid hormonebinding proteins, prealbumin, hyperthyroidism.

Acknowledgments: we thank BML Inc. (Tokyo, Japan) for performing accurate measurements.

Contributions: HK, saw the patient, discussed about the patient, wrote the manuscript; MY, FY, MM discussed about the patient, conducted the project.

Conflict of interests: the authors report no conflicts of interests.

Received for publication: 8 February 2013.

Revision received: 15 March 2013

Accepted for publication: 16 March 2013.

This work is licensed under a Creative Commons Attribution NonCommercial 3.0 License (CC BYNC 3.0)

(C) Copyright H. Kinoshita et al., 2013

Licensee PAGEPress, Italy

Endocrinology Studies 2013; 3:e4

doi:10.4081/es.2013.e4

and TT4) level showed an elevation. Triiodothyronine (FT3 and TT3) level was within normal limits.

Prealbumin is known to transport both T3 and T4; however, it mainly transports T4. ${ }^{1}$ Therefore, the elevation of prealbumin level along with T4 level, as observed in our patient,

Table 1. Thyroid hormones, thyroid hormone carrier proteins, thyroid antibodies in the plasma.

\begin{tabular}{|c|c|c|c|c|c|c|c|}
\hline & Ipril 2011 & May 2011 & July 2011 & Aug 2011 & Nov 2011 & Jan 2012 & Reference \\
\hline TSH & 1.21 & 1.02 & 1.11 & 1.33 & 1.68 & 1.69 & $0.35-4.94 \mathrm{U} / \mathrm{mL}$ \\
\hline FT3 & 2.91 & 2.61 & 2.68 & 2.41 & 2.40 & 2.62 & $1.71-3.71 \mathrm{pg} / \mathrm{mL}$ \\
\hline FT4 & 1.77 & 1.04 & 1.25 & 1.14 & 1.11 & 1.21 & $0.70-1.48$ ng/dL \\
\hline TT3 & & 90 & 95 & 97 & 80 & 106 & $70.0-176.0 \mathrm{ng} / \mathrm{dL}$ \\
\hline TT4 & & 9.3 & 9.5 & 8.6 & 9.3 & 11.3 & $4.8-10.5 \mu \mathrm{g} / \mathrm{dL}$ \\
\hline TBG & & 21.5 & 24.9 & 21.5 & 20.3 & 23.8 & $12.0-28.0 \mathrm{~g} / \mathrm{mL}$ \\
\hline \multicolumn{2}{|c|}{ Prealbumin } & 56.8 & 36.7 & 37.1 & 48.7 & 43.7 & $22.0-40.0 \mathrm{mg} / \mathrm{dL}$ \\
\hline \multicolumn{2}{|c|}{ Albumin } & 4.0 & 4.2 & 4.3 & 4.0 & 3.8 & $3.6-5.1 \mathrm{~g} / \mathrm{dL}$ \\
\hline \multicolumn{2}{|c|}{ Thyroglobulin } & 19.5 & 29.3 & 32.8 & 21.9 & 8.4 & $<32.7 \mathrm{ng} / \mathrm{mL}$ \\
\hline \multicolumn{2}{|c|}{ TRAb } & 3.5 & 4.8 & 2.3 & 4.8 & 2.0 & $<10.0 \%$ \\
\hline \multicolumn{2}{|c|}{ TRAb (human) } & $<1.0$ & $<1.0$ & $<1.0$ & $<1.0$ & $<1.0$ & $<1.0 \mathrm{IU} / \mathrm{L}$ \\
\hline \multicolumn{2}{|c|}{ TSAb } & 113 & 157 & 183 & 156 & 170 & $<180 \%$ \\
\hline \multicolumn{2}{|c|}{ TG antibody } & 171 & 261 & 342 & 354 & 277 & $<0.3 \mathrm{U} / \mathrm{mL}$ \\
\hline \multicolumn{2}{|c|}{ TP0 antibody } & & $>600$ & $>600$ & $>600$ & $>600$ & $>600<0.3 \mathrm{U} / \mathrm{mL}$ \\
\hline
\end{tabular}

TSH, thyroid stimulating hormone: FT3, free triiodothyronine: FT4, free tetraiodothyronine: TT3, total triiodothyronine: TT4, total tetraiodothyronine: TBG, thyroxine-binding globulin: TRAb, TSH receptor antibody: TSAb, TSH receptor-stimulating antibody: TPO, thyroid peroxidase. 
is reasonable. When patients have chronic hyperthyroidism without TRAb, a diagnosis will be Negative Graves' disease. However, a part of patients with Negative Graves' disease may be High prealbumin syndrome.

The T4 distribution in the plasma is as follows: $68 \%$, bound to TBG; $11 \%$, bound to prealbumin; $20 \%$, bound to Alb; and $0.02 \%$, available as free T4 (FT4). ${ }^{1}$ That is, only $11 \%$ of T4 is bound to prealbumin. Therefore, the levels of T4 would not be always high in the patient.

The frequency of patients with high prealbumin level is unknown. However, the findings of the present study may help the diagnosis of hyperthyroidism in cases wherein their cause is unknown. Further studies are required to examine the association between prealbumin and thyroid hormones.

\section{Conclusions}

When patients have chronic hyperthyroidism without thyroid-stimulating hormone receptor antibody (TRAb), a diagnosis will be Negative Graves' disease. However, a part of patients with Negative Graves' disease may be High prealbumin syndrome.

\section{References}

1. Kronenberg HM, Melmed S, Polonsky KS, Larsen PR. Williams textbook of endocrinology. 11th ed. Philadelphia: Saunders Elsevier; 2008. pp 299-332.
2. Burr WA, Ramsden DB, Hoffenberg R. Hereditary abnormalities of thyroxine-binding globulin concentration. A study of 19 kindreds with inherited increase or decrease of thyroxine-binding globulin. Q J Med 1980;49:295-313.

3. Platt HS, Barron N, Giles AF, et al. Thyroidfunction indices in an analbuminemic subject being treated with thyroxin for hypothyroidism. Clin Chem 1985;31:341-2. 